\title{
ANALISIS AKTIVITAS BELAJAR MELALUI PERMAINAN KELOMPOK KOLONG AGAK PADA MATERI BILANGAN BULAT
}

\author{
SUHENDRIK $^{1}$, YUMI SARASSANTI ${ }^{2}$, KURNIA DYAH ANGGOROWATI $^{3}$ \\ ${ }^{I}$ Mahasiswa Program Studi PGSD, STKIP Melawi, Kalimantan Barat \\ suhendrikhen12@gmail.com \\ ${ }^{2}$ Program Studi PGSD, STKIP Melawi, Kalimantan Barat \\ yumisarassanti@yahoo.co.id \\ ${ }^{3}$ Program Studi PGSD, STKIP Melawi, Kalimantan Barat \\ kurniadyah12@yahoo.com
}

First Received: 08-09-2020; Accepted: 28-10-2020

\begin{abstract}
Abstrak
Penelitian ini dilatarbelakangi oleh rendahnya aktivitas belajar siswa kelas IV SD Negeri 12 Seraras Kecamatan Sekadau Hilir. Untuk mengatasi masalah tersebut digunakan permaianan kelompok kolong agak dalam proses pembelajaran mata pelajaran matematika materi bilangan bulat. Penelitian ini bertujuan untuk mengetahui peningkatan aktivitas belajar siswa melalui permainan kelompok kolong agak pada materi bilangan bulat siswa kelas IV SD Negeri 12 Seraras Kecamatan Sekadau Hilir. Metode penelitian ini adalah penelitian deskriptif dengan pendekatan kualitatif. Subjek penelitian ini yaitu siswa kelas IV SD Negeri 12 Seraras Kecamatan Sekadau Hilir sebanyak 16 siswa terdiri dari 8 orang laki-laki dan 8 orang perempuan. Objek penelitian ini yaitu aktivitas belajar siswa pada materi bilangan bulat melalui penggunaan permainan Kelompok Kolong Agak. Teknik pengumpulan data berupa nontes yaitu observasi. Hasil penelitian analisis aktivitas belajar melalui permainan kelompok kolong agak siswa kelas IV SD Negeri 12 Seraras yang dilihat dari hasil lembar obsever menunjukan bahwa pada pertemuan pertama sebesar $65,62 \%$ dan pertemuan kedua $87,5 \%$ meningkat sebesar $23,14 \%$, dari 16 siswa terdapat 15 siswa yang mendapatkan nilai diatas keriteria keberhasilan yaitu 60, dan 8 siswa yang mendapatkan kategori amat baik, 7 siswa mendapat kategori baik dan 1 siswa mendapatkan kategori cukup. Berdasarkan data hasil penelitian dapat disimpulkan bahwa penerapan permainan kelompok kolong agak terhadap proses pembelajaran dapat meningkatkan aktivitas belajar materi bilangan bulat siswa kelas IV SD Negeri 12 Seraras Kecamatan Sekadau Hilir.
\end{abstract}

Kata kunci: Aktivitas belajar; permainan kelompok kolong agak; kearifan local; Sekadau

\section{ANALYSIS OF LEARNING ACTIVITIES THROUGH THE KOLONG AGAK GAME GROUP TOWARD INTEGER NUMBER MATERIALS}

\footnotetext{
Abstract

This study aims to determine the increase in student learning activities through group games under the somewhat in the integer material of fourth grade students of 12 State Elementary School Seraras, Sekadau Hilir District. The form of this research is
} 
descriptive research with a qualitative approach. The research subjects in this study were the fourth grade students of Seraras 12 State Elementary School 12 Sekadau Hilir District. Data collection techniques in the form of nontes namely observation. The results showed that at the first meeting stated from 16 students there were $6.25 \%$ or 1 student got a very good category, $31.25 \%$ or 5 students got good category, $43.75 \%$ or 7 students got enough categories and $18.75 \%$ or 3 students get less categories. The second meeting stated that from 16 students there were $47.05 \%$ or 8 students got very good categories, $43.75 \%$ or 7 students got good categories, $6.25 \%$ or 1 student got enough categories. Based on the data from the research results above, it can be concluded that the results of analyzing learning activities through the undergroup game rather show that the learning activities of the fourth grade students of Seraras 12 Elementary School, sub-district of downstream, increased by $22.22 \%$. The study of analysis of learning activities through under-group games can somewhat improve student learning activities to be an alternative in the learning process innovation.

Keywords: Learning activities; kolong agak game group; local wisdom; Sekadau

\section{PENDAHULUAN}

Berdasarkan observasi dan wawancara di SD Negeri 12 Seraras Kecamatan Sekadau Hilir. Peneliti melakukan wawancara kepada guru wali kelas IV tentang aktivitas belajar dan pembelajaran. Guru menjelaskan bahwa ada beberapa mata pelajaran yang aktivitas belajarnya kurang efektif dan kurang diminati atau disenangi siswa. Ditunjukan dengan nilai akhir siswa beberapa yang belum memenuhi Keteria Ketuntasan Minimal (KKM) salah satunya yaitu mata pelajaran matematika yang ditandai pada saat guru bertanya pada siswa sebelum masuk ke materi yang akan diajarkan masih banyak siswa yang cendrung hanya duduk, diam dan mendengarkan serta tidak memperhatikan.

Aktivitas belajar mata pelajaran matematika materi bilangan bulat masih terpusat pada guru dan menerapkan metode konvensional termasuk metode ceramah yang monoton dan kurang bervariasi, yang membuat kegiatan belajar tidak efektif dan tidak sampai tujuan yang diinginkan oleh guru, sehingga berpengaruh pada sebagian nilai siswa tidak mencapai KKM dengan ditunjukan data oleh guru dari 16 siswa hanya 7 siswa yang mencapai KKM yang telah ditentukan oleh sekolah yakni 60 .

Mata pelajaran matematika materi bilangan bulat harus membutuhkan metode yang menarik dan bervariasi yang melibatkan siswa sendiri dalam menjelaskan materi untuk mewujudkan proses aktivitas belajar yang efektif dan membuat peserta didik merasa senang dan minatnya tinggi untuk mengikuti aktivitas belajar yang bertujuan meningkatkan nilai 
prestasinya. Maka peneliti menerapkan metode permainan kelompok kolong agak untuk menciptakan suasana aktivitas belajar yang menarik dan disenangi oleh peserta didik.

Permainan kelompok kolong agak merupakan permainan kampung yang sering dilakukan siswa dalam kegiatan sehari-hari. Permainan kelompok kolong agak berbentuk lingkaran kecil dan lingkaran besar yang mana siswa untuk saling berbagi informasi pada waktu yang bersamaan. Permainan kelompok kolong agak memiliki langkah-langkah yang sama dengan model inside outside circle yaitu siswa dibagi menjadi beberapa kelompok dengan membentuk lingkaran kecil dan lingkaran besar saling berpasangan, siswa tersebut berbagi informasi atau memberikan pertanyaan kepada pasangannya dengan mendapat gilirannya masing-masing bergeser searah jarum jam.

Model Inside Outside Circle (IOC) atau lingkaran dalam lingkaran luar dikembangkan pertama kali oleh Spencer kagan (1990) dalam buku Miftahul Huda (2013). Model Inside Outside Circle merupakan model pembelajaran lingkaran dalam dan lingkaran luar dimana siswa saling berbagi informasi pada saat yang bersamaan dengan pasangan yang berbeda dengan singkat dan teratur. Model ini sangat baik digunakan dalam aktivitas belajar mata pelajaran matematika khususnya materi bilangan bulat, karena model Inside Outside Circle siswa berperan aktif terhadap materi yang akan diberikan oleh guru. Jadi dalam penelitian ini peneliti mengunakan referensi model Inside Outside Circle sebagai referensi dari permainan Kelompok Kolong Agak karena memiliki langkah-langkah dan tujuan yang sama.

Tabel 1 langkah-langkah permainan kelompok kolong agak dan model Inside Outside Circle

\begin{tabular}{|c|c|c|c|}
\hline & $\begin{array}{c}\text { Permianan Kelompok } \\
\text { Kolong Agak }\end{array}$ & Model Inside Outside Circle & Kegia \\
\hline a) & $\begin{array}{l}\text { Membagikan siswa } \\
\text { menjadi dua kelompok } \\
\text { lingkaran kecil dan } \\
\text { lingkaran besar. }\end{array}$ & $\begin{array}{l}\text { a. Membagikan siswa menjadi } \\
\text { beberapa kelompok yang } \\
\text { beranggotakan 3-4 orang. }\end{array}$ & $\begin{array}{l}\text { 1. Membagikan siswa } \\
\text { menjadi dua kelompok } \\
\text { lingkaran kecil dan } \\
\text { lingkaran besar. }\end{array}$ \\
\hline b) & $\begin{array}{l}\text { Lingkaran kecil } \\
\text { mengahadap ke luar } \\
\text { dan lingkaran besar } \\
\text { menghadap ke dalam. }\end{array}$ & $\begin{array}{llr}b . & \text { Tiap-tiap } & \text { kelompok } \\
\text { mendapat } & \text { tugas mencari } \\
\text { informasi } & \text { berdasarkan } \\
\text { pembagian tugas dari guru. }\end{array}$ & $\begin{array}{l}\text { Lingkaran kecil } \\
\text { mengahadap ke luar dan } \\
\text { lingkaran besar } \\
\text { menghadap ke dalam. }\end{array}$ \\
\hline c) & $\begin{array}{lr}\text { Tiap-tiap } & \text { kelompok } \\
\text { mendapat } & \text { tugas } \\
\text { mencari } & \text { informasi } \\
\text { berdasarkan } & \\
\text { pembagian tugas dari } \\
\text { kelompoknya }\end{array}$ & $\begin{array}{l}\text { c. Setiap kelompok belajar } \\
\text { mandiri, mencari informasi } \\
\text { berdasarkan tugas yang } \\
\text { diberikan }\end{array}$ & $\begin{array}{l}\text { Setiap kelompok belajar } \\
\text { mandiri, mencari } \\
\text { informasi berdasarkan } \\
\text { tugas yang diberikan }\end{array}$ \\
\hline d) & $\begin{array}{l}\text { Tiap kelompok secara } \\
\text { bergiliran memberikan } \\
\text { pertanyaan kepada } \\
\text { pasangannya. }\end{array}$ & 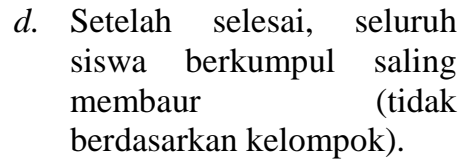 & $\begin{array}{l}\text { Tiap kelompok secara } \\
\text { bergiliran memberikan } \\
\text { pertanyaan kepada } \\
\text { pasangannya. }\end{array}$ \\
\hline e) & $\begin{array}{l}\text { Siapa yang salah } \\
\text { menjawab pertanyaan } \\
\text { dari pasangannya maka } \\
\text { dikenakan hukuman }\end{array}$ & $\begin{array}{l}\text { e. Separuh kelas lalu berdiri } \\
\text { membentuk lingkaran kecil } \\
\text { dan menghadap keluar }\end{array}$ & $\begin{array}{l}\text { Siapa yang salah } \\
\text { menjawab pertanyaan } \\
\text { dari pasangannya maka } \\
\text { dikenakan hukuman }\end{array}$ \\
\hline
\end{tabular}




\begin{tabular}{|c|c|c|c|c|c|}
\hline & $\begin{array}{l}\text { berdasarkan } \\
\text { kesepakatan } \\
\text { kelompok }\end{array}$ & & & & $\begin{array}{l}\text { berdasarkan kesepakatan } \\
\text { tiap kelompok }\end{array}$ \\
\hline f) & $\begin{array}{l}\text { Dua siswa } \begin{array}{r}\text { yang } \\
\text { berpasangan }\end{array} \text { dari } \\
\text { lingkaran kecil diam di } \\
\text { tempat, } \quad \text { sementara } \\
\text { siswa yang berada di } \\
\text { lingkaran r besar } \\
\text { bergeser satu atau dua } \\
\text { langkah searah jarum } \\
\text { jam. }\end{array}$ & f. & $\begin{array}{l}\text { Separuh kelas lainnya } \\
\text { membentuk lingkaran di } \\
\text { luar lingkaran pertama, } \\
\text { menghadap ke dalam }\end{array}$ & 6. & $\begin{array}{l}\text { Dua siswa yang } \\
\text { berpasangan dari } \\
\text { lingkaran kecil diam di } \\
\text { tempat, sementara siswa } \\
\text { yang berada di lingkaran } \\
\text { besar bergeser satu atau } \\
\text { dua langkah searah jarum } \\
\text { jam. }\end{array}$ \\
\hline g) & $\begin{array}{l}\text { Kemudian siswa berada } \\
\text { di lingkaran kecil diam } \\
\text { di tempat, sementara } \\
\text { siswa yang berada di } \\
\text { lingkaran besar } \\
\text { bergeser satu atau dua } \\
\text { langkah searah jarum } \\
\text { jam }\end{array}$ & $g$. & $\begin{array}{l}\text { Dua siswa yang } \\
\text { berpasangan dari lingkaran } \\
\text { kecil diam di tempat, } \\
\text { sementara siswa yang } \\
\text { berada di lingkaran besar } \\
\text { bergeser satu atau dua } \\
\text { langkah searah jarum jam. }\end{array}$ & 7. & $\begin{array}{l}\text { Kemudian siswa berada } \\
\text { di lingkaran kecil besar } \\
\text { di tempat, sementara } \\
\text { siswa yang berada di } \\
\text { lingkaran kecil bergeser } \\
\text { satu atau dua langkah } \\
\text { searah jarum jam. }\end{array}$ \\
\hline h) & $\begin{array}{l}\text { Sekarang giliran siswa } \\
\text { berada di lingkaran } \\
\text { besar yang membagi } \\
\text { informasi. Demikian } \\
\text { seterusnya, sampai } \\
\text { seluruh siswa selesai } \\
\text { berbagi informasi. }\end{array}$ & $h$. & $\begin{array}{l}\text { Kemudian siswa berada di } \\
\text { lingkaran kecil diam di } \\
\text { tempat, sementara siswa } \\
\text { yang berada di lingkaran } \\
\text { besar bergeser satu atau dua } \\
\text { langkah searah jarum jam. }\end{array}$ & & $\begin{array}{l}\text { Sekarang giliran siswa } \\
\text { berada di lingkaran } \\
\text { besar yang membagi } \\
\text { informasi. Demikian } \\
\text { seterusnya, sampai } \\
\text { seluruh siswa selesai } \\
\text { berbagi informasi. }\end{array}$ \\
\hline i) & $\begin{array}{l}\text { Pergerakan baru } \\
\text { dihentikan jika anggota } \\
\text { kelompok lingkaran } \\
\text { dalam dan luar sebagai } \\
\text { pasangan asal bertemu } \\
\text { kembali }\end{array}$ & i. & $\begin{array}{l}\text { Sekarang giliran siswa } \\
\text { berada di lingkaran besar } \\
\text { yang membagi informasi. } \\
\text { Demikian seterusnya, } \\
\text { sampai seluruh siswa selesai } \\
\text { berbagi informasi. } \\
\text { Pergerakan baru dihentikan } \\
\text { jika anggota kelompok } \\
\text { lingkaran dalam dan luar } \\
\text { sebagai pasangan asal } \\
\text { bertemu kembali }\end{array}$ & 9. & $\begin{array}{l}\text { Sekarang giliran siswa } \\
\text { berada di lingkaran } \\
\text { besar yang membagi } \\
\text { informasi. Demikian } \\
\text { seterusnya, sampai } \\
\text { seluruh siswa selesai } \\
\text { berbagi informasi. } \\
\text { Pergerakan baru } \\
\text { dihentikan jika anggota } \\
\text { kelompok lingkaran } \\
\text { dalam dan luar sebagai } \\
\text { pasangan asal bertemu } \\
\text { kembali }\end{array}$ \\
\hline
\end{tabular}

Menurut Sardiman (2006:100), aktivitas belajar meliputi aktivitas yang bersifat fisik maupun mental. Dalam kegiatan belajar kedua aktivitas tersebut harus selalu berkait. Aktivitas belajar siswa sangat kompleks. Paul B. Diedrich (Sardiman, 2006:101), menyatakan bahwa kegiatan siswa digolongkan sebagai berikut:

Tabel 2. Aktivitas Belajar

\begin{tabular}{cl}
\hline \multirow{2}{*}{ Aktivitas fisik } & a. Menyimak \\
& b. Mencatat \\
Aktivitas mental & c. Bekerja sama dalam kelompok \\
\hline \multirow{2}{*}{ Aktivitas emosional } & a. Menyampaikan \\
\hline
\end{tabular}


b. Membuat kesimpulan

Berikut ini adalah aktivitas-aktivitas yang dapat menumbuhkan aktivitas siswa (Yamin, 2007:84) yaitu:

1. Memotivasi siswa untuk aktif dalam kegiatan pembelajaran.

2. Menjelasankan siswa mengenai tujuan yang akan dicapai dalam pembelajaran.

3. Mengingatkan kompetensi prasyarat.

4. Memberikan topik atau permasalahan sebagai stimulus siswa untuk berpikir terkait dengan materi yang akan dipelajari.

5. Menunjukan kepada siswa cara mempelajarinya

6. Memunculkan aktivitas dan partisipasi siswa dalam kegiatan pembelajaran.

7. Memberikan umpan balik (feed back).

8. Memantau pengetahuan siswa dengan memberikan tes.

9. Menyimpulkan setiap materi yang disampaikan di akhir pelajaran.

\section{METODE PENELITIAN}

Prosedur penelitian yang digunakan adalah penelitian analisis deskritif kualitatif. Analisis adalah proses mencari dan menyusun secara sistematis data yang diperoleh dari hasil wawancara, catatan lapangan, dan bahan-bahan lain sehingga dapat mudah dipahami dan temuannya dapat mudah diinformasikan kepada orang lain. Sugiyono (2015:368) sendiri mengemukakan analisis adalah penyusunan hasil observasi, wawancara, catatan lapangan dan dokumentasi secara sistematis.

\section{HASIL DAN PEMBAHASAN}

Hasil penelitian ini didapatkan dari menganalisis aktivitas belajar siswa. Penelitian ini bertujuan untuk menganalisis aktivitas belajar siswa materi bilangan bulat positif dan negatif pada siswa kelas IV SDN 12 Seraras kecamatan sekadau hilir.

Berdasarkan hasil analisis aktivitas belajar melalui lembar obsever pada pertemuan satu $65,62 \%$ dan pertemuan kedua 87,5\% meningkat sebesar 23,14\%, dari 16 siswa terdapat 15 siswa yang mendapatkan nilai di atas kriteria keberhasilan yaitu 70, dan 8 siswa yang mendapatkan kategori amat baik, 7 siswa mendapat kategori baik dan 1 siswa mendapatkan kategori cukup. Disimpulkan bahwa siswa dikatakan sudah baik aktivitas belajar dalam menggunakan permainan kelompok kolong agak. 
Berdasarkan hasil dari menganalisis aktivitas belajar siswa melalui permainan kelompok kolong agak pada materi bilangan bulat siswa kelas IV deskripsi tentang nilai siswa pertemuan pertama sebagai berikut: Siswa yang berinisial AS rendah di aktivitas fisik yaitu mencatat, aktivitas mental yaitu menyimpulkan pesan dan aktivitas emosional yaitu membuat kesimpulan. Siswa yang berinisial DR rendah di aktivitas fisik yaitu bekerja sama dengan kelompok, aktivitas mental yaitu menyimpulan pesan, membuat pertanyaan, menjawab pertanyaan dan aktivitas emosional yaitu menanggapi. Siswa yang berinisial DJ rendah di aktivitas mental yaitu membuat pertanyaan dan menjawab pertanyaan. Siswa berinisial DKS rendah di aktivitas fisik yaitu bekerja sama dengan kelompok, aktivitas mental yaitu menyimpulkan pesan dan aktivitas emosional menanggapi. Siswa yang berinisial $\mathrm{HH}$ rendah di aktivitas fisik yaitu menyimak dan mencatat. Siswa yang berinisial HJ rendah di aktivitas fisik yaitu mencatat dan bekerja sama dengan kelompok, aktivitas mental menyimpul pesan dan menjawab pertanyaan, aktivitas emosional yaitu membuat kesimpulan. Siswa yang berinisial IC rendah di aktivitas mental yaitu menjawab pertanyaan dan aktivitas emosional yaitu menanggapi. Siswa yang berinisial MR rendah di aktivitas mental yaitu membuat pertanyaan dan menjawab pertanyaan, aktivitas emosional yaitu menanggapi. Siswa yang berinisial NAN rendah di aktivitas mental yaitu menyimpulkan pesan dan menjawab pertanyaan. Siswa yang berinisial NR rendah di aktivitas fisik yaitu menyimak, mencatat dan bekerja sama dengan kelompok, aktivitas mental yaitu menyimpulan pesan. Siswa yang berinisial RFR rendah di aktivitas mental yaitu menyimpulkan pesan dan menjawab pertanyaan, aktivitas emosional yaitu menanggapi dan membuat kesimpulan. Siswa yang berinisial SJ rendah di aktivitas mental yaitu menyimpulkan pesan, membuat pertanyaan dan menjawab pertanyaan, aktivitas emosional yaitu menanggapi dan membuat kesimpulan. Siswa berinisial SA rendah di aktivitas fisik yaitu mencatat dan bekerja sama dengan kelompok. Siswa berinisial $\mathrm{T}$ rendah di aktivitas fisik yaitu bekerja sama dengan kelompok. Siswa berinisial UC rendah di aktivitas fisik yaitu bekerja sama dengan kelompok, aktivitas mental yaitu menjawab pertanyaan, aktivitas emosional yaitu menanggapi dan membuat kesimpulan. Siswa yang berinisial SU rendah di aktivitas fisik yaitu mencatat, aktivitas mental yaitu menjawab pertanyaan, dan aktivitas emosional yaitu menanggapi.

Pertemuan kedua, siswa yang berinisial AS meningkat di aktivitas fisik dan mental tetapi masih rendah di aktivitas emosional yaitu membuat kesimpulan. Siswa yang berinisial DR sudah meningkat di aktivitas fisik tetapi masih rendah di aktivitas mental yaitu menjawab pertanyaan dan aktivitas emosional yaitu menanggapi. Siswa yang berinisial DJ sudah 
meningkat dan sangat baik aktivitas belajar yaitu aktivitas fisik, mental dan emosional. Siswa berinisial DKS sudah meningkat di aktivitas fisik tetapi masih rendah di aktivitas mental yaitu menyimpulkan pesan dan aktivitas emosional menanggapi. Siswa yang berinisial HH sudah meningkat dan sangat baik aktivitas belajar yaitu aktivitas fisik, mental dan emosional. Siswa yang berinisial HJ sudah meningkat di aktivitas fisik tetapi masih rendah di aktivitas mental menyimpul pesan dan aktivitas emosional yaitu membuat kesimpulan. Siswa yang berinisial IC sudah meningkat di aktivitas fisik tetapi masih rendah di aktivitas mental yaitu menjawab pertanyaan dan aktivitas emosional yaitu menanggapi. Siswa yang berinisial MR sudah meningkat dan sangat baik aktivitas belajar yaitu aktivitas fisik, mental dan emosional. Siswa yang berinisial NAN sudah meningkat di aktivitas fisik tetapi masih rendah di aktivitas mental yaitu menyimpulkan pesan. Siswa yang berinisial NR rendah di aktifitas fisik yaitu, mencatat dan aktivitas mental yaitu menyimpulan pesan. Siswa yang berinisial RFR sudah meningkat dan sangat baik aktivitas belajar yaitu aktivitas fisik, mental dan emosional. Siswa yang berinisial SJ sudah meningkat di aktivitas fisik tetapi masih rendah di aktivitas emosional yaitu menanggapi dan membuat kesimpulan. Siswa berinisial SA sudah meningkat dan sangat baik aktivitas belajar yaitu aktivitas fisik, mental dan emosional. Siswa berinisial T sudah meningkat dan sangat baik aktivitas belajar yaitu aktivitas fisik, mental dan emosional. Siswa berinisial UC sudah meningkat di aktivitas fisik tetapi masih rendah di aktivitas emosional yaitu menanggapi dan membuat kesimpulan. Siswa yang berinisial SU sudah meningkat di aktivitas fisik tetapi masih rendah di aktivitas mental yaitu menjawab pertanyaan, dan aktivitas emosional yaitu menanggapi.

Berdasarkan data hasil penelitian di atas, hasil analisis aktivitas belajar melalui permainan kelompok kolong agak menunjukan bahwa terjadi peningkatan aktivitas sebesar $22,22 \%$, hal ini ditunjukan dari hasil analisis pertemuan pertama dari 16 siswa hanya terdapat 1 siswa atau 6,25\% yang masuk kategori sangat baik, 5 siswa atau 31,25\% yang masuk kategori baik dan 7 siswa atau 43,75\% yang masuk kategori cukup, dan 3 siswa atau 18,75\% siswa mendapatkan kategori kurang. Pertemuan kedua dari 16 siswa hanya terdapat 8 siswa atau $47,05 \%$ yang masuk kategori sangat baik, 7 siswa atau 43,75\% yang masuk kategori baik dan 1 siswa atau 6,25\% yang masuk kategori cukup.

\section{SIMPULAN}

Dari hasil penelitian yang telah dilakukan, peneliti menarik kesimpulan bahwa analisis aktivitas belajar melalui permianan kelompok kolong agak materi bilang bulat dengan langkah- 
langkah dan aktivitas belajar yang efektif diperoleh data dari observasi aktivitas belajar siswa SDN 12 Seraras Sekadau Hilir dapat meningkatkan aktivitas belajar dengan baik. Hal ini dapat dilihat dari peningkatan persentase aktivitas belajar yaitu aktivitas fisik, mental dan emosional siswa yang mana sebanyak 15 orang siswa sudah mendapatkan kategori baik 15 orang siswa tersebut apabila dipresentasekan yaitu sebesar $87.5 \%$. Jadi, penelitian analisis aktivitas belajar melalui permainan kelompok kolong agak pada materi bilangan bulat siswa kelas dapat meningkatkan aktivitas belajar menjadi lebih baik.

\section{DAFTAR PUSTAKA}

Sardiman, A. M. (2006). Interaksi dan Motivasi Belajar-Mengajar. Jakarta: PT Raja Grafindo Persada

Arikunto, S. (2006). Prosedur Penelitian (Suatu Pendekatan Praktik). Jakarta: Rineka Cipta Ason, Y. (2014). Pendidikan aktivitas belajar siswa dalam perkuliahan psikologi pendidikan dengan metode kerja kelompok. Jurnal Pendidikan Dasar STKIP Melawi: Program Studi Pendidikan Guru Sekolah Dasar (PGSD), 2:164-165

Huda, M. (2013). Model-Model Pengajaran dan Pembelajaran. Yogyakarta: Pustaka Pelajar. Mulyasa, H. E. (2011). Praktik Penelitian Tindakan Kelas. Bandung: Remaja Rosdakarya Offset.

Sugiyono. (2015). Metode Penelitian Kuantitatif, Kualitatif, dan R\&D. Bandung: Afabeta Suyono. (2017). Belajar Dan Pembelajaran. Bandung: Remaja Rosdakarya.

Yamin, M. (2007). Profesionalisasi Guru \& Implementasi KTSP. Jakarta: Gaung Persada Press 